\section{The Morality of Killing Human Embryos}

$\mathrm{E}$ mbryonic stem cell research is morally and politically controversial because the process of deriving the embryonic stem (ES) cells kills embryos. If embryos are, as some would claim, human beings like you and me, then ES cell research is clearly impermissible. If, on the other hand, the blastocysts from which embryonic stem cells are derived are not yet human beings, but rather microscopic balls of undifferentiated cells, as others maintain, then ES cell research is probably morally permissible. Whether the research can be justified depends on such issues as its cost, chance of success, and numbers likely to benefit. But this is an issue for any research project, not just ES cell research. What makes the debate over ES cell research controversial is that it, like the debate over abortion, raises "questions that politicians cannot settle: when does human life begin, and what is the moral status of the human embryo?"1 This paper looks at several theories of moral status and their implications for embryo research.

When we ask whether a being has moral status, we are asking whether it counts or matters from the moral point of view; whether it must be considered in our moral deliberations. It seems obvious that not everything has moral status. We are not required to consider the impact of our moral decisions on mere things - for example, ordinary rocks. It seems equally obvious that paradigmatic people - people like you and me - do have moral status. In fact, most people take it for granted that even if moral status isn't limited to people (that animals count, for example) human beings count for more. To express this in Kantian terms, humanity has a dignity and worth which separates humankind from the rest of creation. Because this view is commonplace in moral thinking and in the law, we can call it the common-sense view of moral status.

\section{The Common-Sense View: The Biological Humanity Criterion}

The common-sense view of moral status is derived from the Judeo-Christian tradition which teaches that only human beings are created in God's image, and therefore human beings alone have this special moral status. In addition, this special moral status belongs to all human beings, regardless of race, ethnicity, nationality, or gender. We are all God's children. Compared to views that limit moral status to members of one's own group or tribe, the Judeo-Christian view is quite progressive. Theoretically (though often not in reality), it prohibits the enslaving or killing of other

Bonnie Steinbock, Ph.D., is Professor of Philosophy at the University at Albany. Her areas of specialization within bioethics include reproduction and genetics. 
human beings, simply because they are "outsiders." The secular version of this view bases the unique moral status of humanity on a biological category - membership in the species homo sapiens.

The biological humanity criterion of moral status states that all and only human beings, members of our species, have full moral status. But even those who agree on the criterion may differ on this question: when does a human being come into existence? Sometimes this is put in a different way: when does human life begin? But this question, familiar from the abortion debate, poses the issue in a misleading way, because every cell in your body is both human (possessed of a human genome) and alive. Human gametes (ova and sperm) are alive, and sperm even swim. So the question, "when does human life begin?" is better understood as asking, "when does an individual human organism come into existence?”

One answer is that a human organism comes into existence at conception. Those who hold the conception view adopt the biological humanity criterion of moral status, which says that all and only human organisms have full moral status. In addition, they believe that a human organism exists at the moment of conception. Indeed, they usually hold that this is a plain matter of biological fact.

However, this is dubious, as there are biological reasons to think that the unique human organism begins to exist only some time after the beginning of fertilization. Fertilization or conception does not occur at a precise moment. It is a process taking place over hours, even days. The process of conception is not completed until syngamy, when the chromosomes from the egg and the sperm have merged, some time after the sperm has penetrated the egg. However, even syngamy may not mark the beginning of a human organism. Ron Green points out,

biologists usually describe the cells of an organism has having the full range of cellular structure including a single cell nucleus that contains DNA within its own nuclear membrane. But at syngamy the zygote has no definitive nuclear membrane... A distinctive diploid cell nucleus does not make its appearance until the two-cell stage, after the zygote undergoes its first cell division... ${ }^{2}$

Moreover, in the early stages of an embryo's life, many of its cells, or blastomeres, remain "totipotent." This means that each blastomere is undifferentiated and remains capable, if properly manipulated, of developing into a full human being. One kind of cloning - called embryo splitting or blastomere separation - is accomplished in this way. Embryo splitting also occurs naturally in the case of identical twins (or triplets). Green comments, "if biological humanness starts with the appearance of a unique diploid genome, twins and triplets are living evidence that the early embryo is not yet one human being, but a community of possibly different individuals held together by a gelatinous membrane." ${ }^{3} \mathrm{He}$ goes on to quote an embryology text as saying, "a genetically unique but non-individuated embryo has yet to acquire determinate individuality, a stable human identity." In this view, a genuine human organism begins to exist only after twinning is no longer possible: at the beginning of gastrulation when the primitive streak (the precursor of the nervous system) forms. In a pregnancy, gastrulation coincides with implantation, the imbedding of the embryo in the uterus, which occurs about fourteen days after fertilization.

The debate over when a human organism comes into existence occurs within the context of the biological humanity criterion. However, the criterion itself has been challenged.

\section{The Person View}

In her classic article, "On the Moral and Legal Status of Abortion," Mary Anne Warren argues that the conservative view on abortion rests on a confusion between two distinct senses of "human being." One sense is biological or genetic. It refers to the species to which an entity belongs. Human fetuses are unquestionably human in the biological sense. However, it does not follow from their genetic humanity that they are human in the other sense, the moral sense, which refers to their moral status and rights. Why should a biological category confer a special moral status? The belief that humanness does imply such a status and rights (human rights) stems from a failure to distinguish between the two senses. To avoid this confusion, Warren suggests that we reserve the term "human" for the biological or genetic sense, and use the term "person" to refer to beings who are full-fledged members of the moral 
community, possessed of moral rights - in particular, the right to life. This enables us to avoid begging the question in the abortion debate, for it remains an open question whether a human fetus is a person with a right to life.

Why not base moral status and moral rights on species membership? After all, all the persons we know are, in fact, members of the species homo sapiens. Why not use species membership as a marker for moral personhood? The reason is the arbitrariness of limiting moral status to genetic human beings. This can be seen if we imagine coming across an extraterrestrial like the eponymous character in the movie, E.T. If we were deciding what it would be morally permissible to do to him - say, put him in a zoo, or make him into hamburger - surely the question would not be decided by the number of chromosomes in his cells (if he even had chromosomes). His not being a member of the species homo sapiens would not determine his moral status. It seems likely that we would regard him as a person - a non-human person - with all the rights of any one of us.

The example of E.T. is meant to show that biological humanity isn't a necessary condition of full moral status. Instead, moral status is based on certain psychological characteristics, such as sentience, consciousness, self-consciousness, the ability to use language, rationality, and moral agency. These characteristics are typical of members of our species, but not necessarily limited to them, as the example of E.T. is intended to show. Moreover, there seem to be members of our species who lack these person-making characteristics, such as anencephalic babies and patients in persistent vegetative states. They are biologically human, but not persons, and thus do not have the moral status reserved to persons.

An objection made to the person view is that, without an account of the moral relevance of person-making characteristics, it is as arbitrary as a theory based on species membership. Why should moral status and moral rights be limited to sentient, self-conscious, language-using, rational agents? Moreover, depending on how many person-making characteristics are needed for full moral status and rights, the person view appears to exclude those human beings who, due to severe developmental disabilities or mental illness or senility, or even infancy, do not have the capacity to reason or use language. It is hard to accept that human beings in these categories - who are often members of our own families - are not moral persons, with the same moral status and rights as the rest of us. Advocates of the biological humanity criterion maintain that any criterion other than genetic humanity will have this fatal flaw.
The challenge, then, is to construct a theory of moral status that is neither arbitrary (like the biological humanity criterion) nor unduly restrictive (like the person view). Moreover, the view should explain the moral relevance of its criterion for moral status.

\section{The Interest View ${ }^{6}$}

The interest view bases moral status on the possession of interests. The view derives from Joel Feinberg's "interest principle," 7 which was intended to answer the question, what kinds of beings can logically have rights? Feinberg suggests that the answer comes from the purpose or function of rights, which is to protect the interests of the being alleged to have the rights. He usefully analogizes having an interest in something to having a "stake" in it. I am better off if the things in which I have a stake, such as my health, my career, my assets, my family, flourish or prosper. Their flourishing is in my interest. Feinberg writes:

One's interests, then, taken as a miscellaneous collection, consist of all those things in which one has a stake, whereas one's interest in the singular, one's personal interest or self-interest, consists in the harmonious advancement of all of one's interests in the plural. These interests...are distinguishable components of a person's well-being: he flourishes or languishes as they flourish or languish. What promotes them is to his advantage or in his interest; what thwarts them is to his detriment or against his interest. ${ }^{8}$

This is not to claim a one-to-one connection between what a person desires and what is in his self-interest. I can take an interest in something (like junk food) that is not in my interest; and something can be in my interest but not be something I take an interest in (like exercise). But the reason exercise is in my interest, and junk food is not, is that exercise promotes other goals and desires of mine, such as staying healthy and alive, and eating junk food does not. If I had no desires, goals, or preferences at all, nothing would be in my interest.

Unless a being has interests and a welfare of its own, it makes no sense to ascribe rights to it. Feinberg's insight about the logical conditions of having rights can be applied more generally to having moral status. To have moral status is to count or matter, from the moral point of view. If a being has moral status, then its interests must be considered when we engage in moral deliberation. If a being has no interests, its interests cannot be considered. So the possession of interests is a necessary condition of having moral status, and I would argue that it is also a sufficient condition. That is, if a being has interests, there is no justification for 


\section{It matters to sentient beings what one does to them, and this is why they have moral claims on us. To take a homely example, it is fine if a child plucks the petals off a daisy while saying, "He loves me, he loves me not." It is not fine if the child recites the rhyme while pulling legs off an insect, or the feathers off a (trapped) bird.}

ignoring those interests when making moral decisions. (It is a separate question how much weight to accord to the interests of different beings, that is, whether there are other factors that give some beings a higher moral status than others.)

The Feinbergian account of having interests as having stakes in things suggests a conceptual link between interests and consciousness. Only conscious beings - beings with some sort of mental life, however rudimentary - can have wants; only beings with wants can have a stake in anything; only beings that can have a stake in something can have interests of their own. Non-conscious beings, whether mere things (like cars and rocks and works of art) or living things without nervous systems (like plants), have no interests of their own. This is not to say that they cannot be cared for or neglected; repaired or destroyed; nourished or killed. It is rather to say that it does not matter to non-conscious beings what we do to them. We can preserve their existence, and even promote their welfare in the sense of making them better entities of a certain kind. For example, we can fertilize the roses so that they grow vigorously and bloom; we can bring in the car for regular service so that it runs beautifully. However, we cannot do these things out of concern for what matters to them, because nothing matters to them. They do not have a stake in anything, including their own existence. For this reason, I maintain that they, unlike conscious beings, do not have a welfare or sake of their own.

Some will object that we cannot base moral status on consciousness unless we have a definition of consciousness, but there does not seem to be any satisfactory, non-circular definition. Acknowledging the problem, David Boonin says, "It is tempting to say that to be conscious is to be aware of something, for example, but then awareness will surely have to be defined in terms of being in a conscious state." What follows from the absence of a definition of consciousness? Not much, Boonin argues. It is not as if we had no idea what consciousness is. He writes:

As Nagel famously put it, using an expression that has since become ubiquitous in discussions of the subject, "an organism has conscious mental states if and only if there is something that it is like to be that organism - something it is like for the organism." Even if this does not constitute a definition of consciousness, you do know what I am talking about when I refer to the fact that there is something that it is like to be you when you see a clear blue sky, hear a shrill scream, feel a sharp prick, or a cold wind, or a burning itch. And this is enough to make clear what is meant by the claim that there is a morally relevant difference between an organism that is conscious in this sense and an organism that is not. ${ }^{10}$

The morally relevant difference between conscious and non-consciousness beings is that conscious beings have interests and a welfare of their own, compounded out of those interests. Non-conscious beings do not have either of these things.

Sentience is only one form of conscious awareness, but it is a very important one. If a being is sentient, that is, it can experience treatment as painful, it has at least one interest: the interest in not experiencing pain. The fact that a being can suffer gives us a reason to treat it in certain ways, and not in other ways. It matters to sentient beings what one does to them, and this is why they have moral claims on us. To take a homely example, it is fine if a child plucks the petals off a daisy while saying "He loves me, he loves me not." It is not fine if the child recites the rhyme while pulling the legs off an insect, or the feathers off a (trapped) bird.

Implications of the Interest View for Embryos Embryos are not mere things. They are alive and, under certain conditions, have the potential to become beings with interests - indeed, to become people, like you and me. But their potential to become persons does not give them the moral status or the rights of actual persons. Early embryos, indeed early-gestation fetuses, have no consciousness, no awareness, no experiences of any kind, even the most rudimentary. Without even the precursor of a nervous system, pre-implantation embryos cannot possibly have any kind of consciousness. Without consciousness, they cannot have desires; without desires, they cannot have interests. It is not wrong to kill embryos because it doesn't matter to an embryo whether it is killed or goes on living. Its con- 
tinued existence is clearly not something an embryo takes an interest in, because it is impossible for a nonconscious, non-sentient being to take an interest in anything. More importantly, the interest view maintains that continued existence is not in the interest of a non-sentient fetus. For continued existence to be in its interest, it would have to have a welfare of its own, compounded out of all of its interests taken together. Lacking interests, embryos do not have a welfare of their own. In this respect, they are like gametes. Gametes are alive and human, but this is not sufficient for moral status. To have moral status is to be the kind of being whose interests and welfare we moral agents are required to consider. Without interests, there is nothing to consider. This is not to say that there might not be other reasons, including moral reasons, to protect non-interested beings. It is to say that these reasons cannot stem from their own interests or welfare, since they have none. Indeed, on a plausible conception of harming as setting back a being's interests, it follows that killing non-interested beings does not harm them. ${ }^{11}$ If this sounds odd, it is because, for $u s$, being killed is ordinarily the greatest of harms. But that is because we have interests, and in particular, an interest in continuing to exist. However, if a being has no interests, death is not a harm to it, any more than being destroyed is a harm to an automobile.

Of course, embryos differ from automobiles in one very significant way: embryos are living beings with the potential to develop into human persons, just like you or me, if they are not killed. In a now-classic article, Don Marquis argues that it is wrong to kill fetuses for the very same reason that it is wrong to kill you or me: because doing so deprives them (and us) of our valuable futures. In the next section, I will assess the Valuable Futures argument and its implications for the morality of killing embryos.

\section{Marquis and the Valuable Futures Argument}

According to Marquis, both sides of the abortion debate have insurmountable problems. What is needed is a fresh start, an account of why killing is wrong in the paradigm cases in which everyone would agree that it is wrong - namely, the killing of adult human beings, like you or me. Killing adult human beings is prima facie wrong because killing them deprives them of their future. Marquis writes:

The loss of one's life is one of the greatest losses one can suffer. The loss of one's life deprives one of all the experiences, activities, projects, and enjoyments that would otherwise have constituted one's future. Therefore, killing someone is wrong, primarily because the killing inflicts (one of) the greatest pos- sible losses on the victim.... When I am killed, I am deprived both of what I now value which would have been part of my future personal life, but also what I would come to value. Therefore, when I die, I am deprived of all of the value of my future. Inflicting this loss on me is ultimately what makes killing me wrong. This being the case, it would seem that what makes killing any adult human being prima facie seriously wrong is the loss of his or her future. ${ }^{12}$

But exactly the same is true of killing a human fetus, and so abortion is, prima facie, wrong. Prima facie because killing is wrong only if it deprives the one killed of a "valuable future" or a "future-like-ours" (FLO, as it has come to be referred to). Thus, the valuable futures argument does not imply that it is wrong to kill someone in a persistent vegetative state (PVS) because someone in PVS no longer has a valuable future. It's also consistent with voluntary euthanasia, because persons who are severely and incurably ill and who face a future of pain and despair and who wish to die will not have suffered a loss if they are killed, because the future of which they are deprived is not considered by them to be a valuable one. Equally, the aborting of fetuses with defects so severe as to prevent them having FLO might be justifiable on Marquis's account. How severe would the disabling condition have to be to make abortion morally permissible? Is it only lethal conditions (such as Tay-Sachs disease) which deprive fetuses of FLO? Or could non-lethal conditions, such as mental retardation, deprive a fetus of FLO, and thus justify abortion? Marquis does not address these sorts of questions, indeed, does not provide an account of "just what it is about my future or the futures of other adult human beings which make it wrong to kill us."13 His aim is, rather, to show that abortion is in general a grave wrong. For most fetuses clearly do have valuable futures. If they are not aborted, they will come to have lives they will value and enjoy, just as you and I value and enjoy our lives. Therefore, abortion is seriously wrong for the same reason that killing an innocent adult human being is seriously wrong: it deprives the victim of his or her valuable future.

On the interest view, the killing of non-sentient beings is not seriously wrong because non-sentient beings are not deprived of anything they want or have a stake in by being killed. Marquis thinks that this reveals a fundamental flaw in the interest view, or indeed in any sentience- or desire-based view. First, it seems to imply that it is not wrong to kill someone in a reversible coma or even in deep and dreamless sleep. Such a person is not now conscious or sentient. If we explain the wrongness of killing him by appealing to his future 
conscious states, then it seems that it is equally wrong to kill a pre-conscious fetus, who will become conscious and sentient in the natural course of events, if it is not aborted. Either the interest view entails that it is morally permissible to kill temporarily comatose adults, in which case it cannot be the right view of moral status, or it must concede that it is wrong to kill fetuses, in which case it cannot be the basis for a defense of abortion. By contrast, the FLO account can explain the wrongness of killing temporarily unconscious adults; this deprives them of their valuable futures.

Second, Marquis argues, the interest view cannot explain why it is wrong to kill someone who is conscious and sentient, but who does not want to go on living. If it is the desire to go on living that makes killing someone seriously wrong, then presumably it is not wrong to kill someone who does not have the desire to go on living, due to (treatable) depression. But of course, Marquis argues, it $i s$ wrong, and the FLO account can explain why. A person can have a valuable future, even if, due to depression, he does not now have the desire to go on living. It would be seriously wrong to kill him and thereby to deprive him of that valuable future. (Presumably it would not be wrong to kill someone whose depression was untreatable and who faced "a future of pain and despair." At least, it would not wrong

\section{Abortion is seriously wrong for the same reason that killing an innocent adult human being is seriously wrong: it deprives the victim of his or her valuable future.}

the person killed, though Marquis leaves it open that there might be other reasons why killing him would be wrong.)

The interest view is not vulnerable to these alleged counter-examples. The difference between a fetus and a temporarily comatose adult (TCA) is that a TCA has desires, including a desire to go on living, that make it seriously wrong to kill him. The same is not true of an embryo or first-trimester fetus, which has no desires at all. ${ }^{14}$ Admittedly, a TCA does not have any conscious desires. But even while he is unconscious, he still has desires, just as he still has beliefs. David Boonin points out that not all of our beliefs are ones of which we are consciously aware: they are not all occurrent beliefs. To illustrate the dispositional nature of many of our beliefs, Boonin gives the following example. Ten minutes ago you probably were not consciously aware of believing that a triangle has three sides. Yet if I were to ask you, "how many sides does a triangle have?" you would be disposed to answer, "three." That is why it is a dispositional belief. Nevertheless, it is one of your beliefs, a belief you already have. As Boonin puts it, "you do not lose all of your beliefs each time you go to bed and then acquire a new and identical set of beliefs each time you wake up. You retain your beliefs as dispositional beliefs and occasionally have some or others as occurrent beliefs." 15

Similarly, if you desire not to be killed, you continue to have that desire dispositionally while you are in a reversible coma. On the basis of this desire, we can ascribe to you an interest in continued existence, an interest that exerts a moral claim on the rest of us not to kill you while you are temporarily comatose. But the same cannot be said of a being, like an embryo, that has never been conscious and so has no desires, occurrent or dispositional, and hence no interests.

In a forthcoming article, "Abortion Revisited," Marquis writes, "Boonin's account of and defense of a dispositional desire strategy for dealing with the alleged temporarily unconscious adult counterexample to the present desire view seems reasonable."16 I take this to mean that Marquis now agrees that the alleged counter-example of the temporarily comatose adult is not a problem for desire- or sentience-based accounts. But what about someone who has no desire, occurrent or dispositional, to go on living, due to severe but temporary depression? Can the interest view explain why it would be seriously wrong to kill such a person without at the same time implying that it would be seriously wrong to kill a fetus?

Boonin responds by arguing that sometimes we need to correct a person's actual desires because, due to various distorting conditions, they do not represent what the individual really wants. He writes, “...in many cases in which we believe that the present desires of others are morally significant, we distinguish between the actual content of the desire that a person has given her actual circumstances and the content the desire she actually has would have had if the actual desire had been formed under more ideal circumstances." ${ }^{17}$ In the case of the depressed person who does not want to live, it is the depression that makes him unable to think clearly and unable to enjoy his life. When he comes out of the depression, life will seem to him to be worth living again. So of course it would be seriously wrong to kill him while he is in the depressed state. As Boonin puts it, “...when someone's desires are such that they would very strongly desire that you not do something to them were they able to reflect more clearly on the question, then that counts as a very strong moral reason not to do it." 18

Marquis thinks that the case of the depressed person ("Hans" in Boonin's example) and the fetus are analo- 
gous. If what makes killing Hans seriously wrong is that Hans would want to go on living if he were able to think clearly, then why can't we say that what makes killing the fetus wrong is that it would want to go on living, if it could think about it. This is not like saying that a rock would want to go on living if it could think about it, because unlike a rock, a fetus has a future of value, that is, a life that it will value in the future. In this respect, the fetus is just like Hans. And so Marquis writes, "Fetuses are quite different. Hypothetical desires can be attributed as easily to fetuses as to Hans."19 However, fetuses do not have distorted desires, which need correcting in order to perceive what they really want. Preconscious fetuses do not have desires at all. It seems to me one thing to ascribe an ideal or hypothetical desire to a person whose desires have been distorted, and quite another to ascribe hypothetical desires to a being incapable of having any desires. In any event, I am not sure how much Marquis wants or needs to base his argument on the ascription of hypothetical desires to fetuses, as he has a different argument, which is not dependent on the existence of such desires. He suggests that we can "...attribute interests to a presently insentient being in virtue of its well-being at some future sentient stage of its natural history."20 In other words, although the fetus is now unconscious and has no desires, it can still have an interest in its future, in the sense that its future is in its interest. The motivation for this claim is the view of the fetus as just one stage in a person's natural history. If my life and my future existence are something I value, then it is rational for me to be glad that I was not killed at an earlier stage, for example, when I was a fetus. My valuable future is its valuable future. Having that future (that is, not being killed) is as much in its interest as it is in mine. Or rather, not being killed is as much in my interest when I was a fetus as it is in my interest now.

\section{McMahan's Mind Essentialism}

So the next question is, was I ever a fetus? That may seem indisputable, given the biological facts. Everyone, surely, started life as a zygote, which developed into an embryo, which became a fetus, and then was born as a baby. However, this is exactly what Jeff McMahan wants to deny. He writes,

...even if we grant that a new human organism begins to exist at conception, it follows from this fact that we began to exist at conception only if we are human organisms....if I am a human organism, I began to exist when this organism did. But the assumption that I am numerically identical with the organism with which (to put it as neutrally as possible) I coexist is hardly uncontroversial. ${ }^{21}$
McMahan thinks that the most plausible account of what I essentially am is an embodied consciousness. And if that's the case, then I never existed as a nonconscious fetus. I came into existence when my organism began to be conscious - sometime between 20 and 28 weeks of gestation. ${ }^{22}$ Summarizing McMahan's position, David DeGrazia writes,

...the thesis of mind essentialism implies that early fetuses, lacking minds, cannot become minded beings, since it asserts that anything that is ever minded is always minded. Thus, early abortions do not kill beings with significant moral status, making these abortions "relevantly like contraception and wholly unlike the killing of a person." The Valuable Futures Argument therefore trips on the mistaken assumption that the early fetus will develop into a minded being. Because it will not, the early fetus does not have a valuable future. ${ }^{23}$

McMahan's theory provides a neat response to Marquis - but only if one accepts his mind essentialism, and the idea that the preconscious fetus cannot develop into a conscious fetus, much less a person like you or me. That seems to me to fly in the face of the facts. It seems much more plausible to say that I was once a child, and before that an infant, and before that a fetus. Boonin, commenting on the pictures in his office of his son, Eli, at various stages after birth, says, "through all of the remarkable changes that these pictures preserve, he remains unmistakably the same little boy." He also has another picture of Eli taken 24 weeks before his birth. Boonin writes, "there is no doubt in my mind that this picture, too, shows that same little boy at a very early stage in his physical development." ${ }^{24}$ McMahan would have to say that the sonogram is a picture of Eli's organism at a very early stage, but it is not a picture of Eli. I would say (and I assume Boonin would agree) that I am my organism, although this is not all that I am. However, to posit a "me" that is distinct from my physical self seems implausible, and the wrong way to defend abortion. Rather, I would say that when I was a fetus, it would have been permissible to abort me, because had I been aborted before I became conscious and sentient, it would not have mattered to me. It would have made no more difference to me than preventing my conception. So while I agree with Marquis that I was once a fetus, I deny that when I was a fetus, I had an interest or a stake in my valuable future. I think that when I was a mindless fetus, I had no interests at all.

\section{Implications for Blastocysts}

I began this paper with the question whether it is seriously wrong to kill embryos at the blastocyst stage. I 
want to suggest now that even if Marquis is right about the morality of abortion - that it's wrong to kill fetuses because they have valuable futures it is not plausible to claim that pre-implantation embryos do. For unlike a fetus, an extracorporeal embryo is not developing into someone with a valuable future. Left alone (that is, not aborted), the fetus will (most likely) develop into someone with a valuable future. But the same is just not true of an embryo, whether left-over from IVF or deliberately created for research. Left alone, an extracorporeal embryo will just die. That's not much of a valuable future.

It might be argued that the blastocyst could be implanted into a uterus, where it too would develop into a baby, and thus it has, hypothetically, a valuable future. Of course, this is true only of viable embryos. Non-viable embryos - embryos incapable of further development - cannot have valuable futures. Presumably, even on Marquis's view, it would be morally permissible to use non-viable embryos left over from infertility treatment in embryo research (although I do not know if the stem cells derived from non-viable embryos could be used in treating disease, should ES cell therapies ever be developed).

Most opponents of ES cell research make no distinction between embryos created by IVF and embryos created by cloning. However, on the Valuable Futures approach, there might be a considerable difference. We know that it is possible, under some set of conditions, for an IVF embryo to develop into a baby. Over 35,000 babies were born in the United States alone in 2000 (ASRM/SART Registry 2004). By contrast, biologist Rudof Jaenisch maintains that "a cloned embryo has little, if any, potential to develop into a normal human being." He explains:

By circumventing the normal processes of gametogenesis and fertilization, nuclear cloning prevents the proper reprogramming of the clone's genome ...which is a prerequisite for the development of an embryo into a normal organism. It is unlikely that these biologic barriers to normal development can be overcome in the foreseeable future..$^{25}$

Jaenisch hastens to point out that the embryonic stem cells derived from a cloned embryo are functionally indistinguishable from those derived from IVF embryos, making them equally useful as a source for ES cells in research or therapy.

The chance a human embryo has of developing into a normal human being is irrelevant from the perspective of the biological humanity criterion. What matters for moral status is that the embryo is a human organism (although, as we have seen, there is considerable debate about when a human organism comes into existence). On this criterion, the moral status of the embryo is determined by its genetic humanity, not what it can or cannot develop into. Marquis, however, explicitly rejects the genetic humanity criterion, because it is hard to see why a merely biological category should make a moral difference. Clearly, he is sympathetic to this objection expressed by pro-choicers: "why, it is asked, is it any more reasonable to base a moral conclusion on the number of chromosomes in one's cells than on the color of one's skin?" ${ }^{26}$ By contrast, on the Valuable
It seems to me one thing to ascribe an ideal or hypothetical desire to a person whose desires have been distorted, and quite another to ascribe hypothetical desires to a being incapable of having any desires.
Futures approach, the developmental potential of an embryo makes all the difference in the world, since if a cloned embryo cannot develop into someone like you or me, it cannot have FLO. Killing it does not deprive it of its valuable future, and therefore, presumably, is not seriously wrong.

This has interesting implications for the "created/ spare" distinction, appealed to by the National Bioethics Advisory Commission (NBAC) in its report, Cloning Human Beings. According to NBAC, it would be wrong to create embryos solely for the purpose of research; to do so would be inconsistent with the respect due to embryos as a form of human life. However, it would be ethically permissible to use embryos created for reproductive purposes, which are no longer needed (socalled "spare" embryos), since these embryos would be discarded anyway. President Bush considered this argument in his August 6, 2001 address to the nation, but ultimately rejected it. He maintained that it was impermissible to kill any embryos, even those that would be discarded anyway. On the valuable futures approach, it appears that the created/spare distinction has moral relevance, though precisely opposite to that claimed by NBAC. Whereas NBAC argued that only spare embryos can be ethically used (and destroyed) in research, in the valuable futures approach, it would be morally acceptable to use cloned human embryos as sources of stem cells since they lack FLO, but unacceptable to use embryos discarded after fertility treatment, since they have FLO. They have FLO because they could be used to make babies, even if their creators do not wish 
to use them for this purpose. This is a rather startling implication of the Valuable Futures argument. The claim that it is morally better to use cloned embryos rather than embryos left over from infertility treatment is not one that I have seen anywhere in the Valuable Futures literature.

My own view is that we should reject the created/ spare distinction, although not for the reason President Bush gave. I think that it is permissible to use human embryos in research that kills them because embryos lack moral status. In my view, it makes no difference what the source of the embryos is, whether they are created by IVF or cloned; whether they are created specifically for research purposes or are left over from infertility treatment. However, I do not think it is permissible to use embryos for frivolous or trivial purposes. I maintain that respect for human life requires that human embryos be used for morally important purposes, but that is a topic for another paper. ${ }^{27}$

\section{References}

1. S. G. Stolberg, "Controversy Reignites Over Stem Cells and Clones," Nerw York Times, December 18, 2001, at F1.

2. R. M. Green, The Human Embryo Research Debates (New York: Oxford University Press, 2001): at 28.

3. Id., at 29 .

4. See also J. A. Robertson, Children of Choice: Freedom and the Nerw Reproductive Technologies (Princeton: Princeton University Press, 1994): at 251, note 13: "...recent studies suggest that a new genome is not expressed until the four- to eight-cell stage of development." See Braude, Bolton, and Moore, "Human Gene Expression First Occurs Between the Four and Eight-Cell Stages of Preimplantation Development," Nature 332 (1988): at 459, 460.

5. M. Warren, "On the Moral and Legal Status of Abortion," The Monist 57, no. 1, (1973): 43-61. Warren's views have changed since 1973 , and her current views on moral status are given in her book, Moral Status. Nevertheless, her earlier article is an excellent statement of the person view, a view that many people continue to hold.

6. I develop the interest view in chapter 1 of my book, Life Before Birth: The Moral and Legal Status of Embryos and Fetuses (New York: Oxford University Press, 1992).

7. J. Feinberg, "The Rights of Animals and Unborn Generations," in William T. Blackstone, ed., Philosophy \& Environmental Crisis (Athens: University of Georgia Press, 1974).

8. J. Feinberg, Harm to Others (New York: Oxford University Press, 1984): at 34

9. D. Boonin, A Defense of Abortion (Cambridge: Cambridge University Press, 2003): at 102.

10. Id., at 102-103, citing T. Nagel, "What is it Like to be a Bat?" in T. Nagel, Mortal Questions (Cambridge: Cambridge University Press, 1979): at 166.

11. Some philosophers apparently reject the idea that harming involves the setting back or thwarting of a being's interests. See, for example, E. Harman, "The Potentiality Problem," Philosophical Studies 114 (2003): 173-198. Harman thinks that it is obvious that beings without moral status can be harmed, and gives the following example: The deprivation of light harms a weed. However, the reason why I maintain that a weed is not harmed when it is killed is not that weeds lack moral status. Rather, it is that I agree with Feinberg that harming involves the setting back or thwarting of interests. Since weeds (or prize orchids, for that matter) do not have interests, they cannot be harmed, though they can be killed. To show that this is wrong, one would need to give an alternate account of harming, something Harman does not do.

12. D. Marquis, "Why Abortion is Immoral," The Journal of Philosophy 86, no. 4 (1989): 183-202, at 189-190.

13. Id., at 191 .

14. In Life Before Birth, I argued that sentience was unlikely until well into the second trimester. "Pain perception requires more than brain waves. It involves the development of neural pathways and particular cortical and subcortical centers, as well as neurochemical systems associated with pain transmission. In light of this, it seems extremely unlikely that a first-trimester fetus could be sentient," B. Steinbock, supra note 6, at 189. This is consistent with moral recent findings of researchers on fetal pain. Vivette Glover and Nicholas Fisk write, "To experience anything, including pain, the subject needs to be conscious, and current evidence suggests that this involves activity in the cerebral cortex and possibly the thalamus. We do not know for sure when or even if the fetus becomes conscious. However, temporary thalamocortical connections start to form at about 17 weeks and become established from 26 weeks. It seems very likely that a fetus can feel pain from that stage." V. Glover and N. Fisk, British Medical Journal 313 (1996): 796. For this reason, Glover and Fisk suggest that more attention should be paid to pain relief during labor and delivery for the baby as well as the mother, and that safe methods of administering analgesia to the fetus in late terminations (after 20 weeks) should be developed. At the same time, in an interview with the BBC, Dr. Glover stressed that it is incredibly unlikely that a first-trimester fetus can feel pain because there is no linking to the brain at all. Editor, "Abortion Causes Foetal Pain," $B B C$ Neres, at <http://news.bbc.co.uk/1/hi/health/900848.stm> (last visited December 6, 2005).

15. D. Boonin, A Defense of Abortion (Cambridge: Cambridge University Press, 2003): at 65-66.

16. D. Marquis, "Abortion Revisited," in B. Steinbock, ed., The Oxford Handbook of Bioethics (Oxford: Oxford University Press, forthcoming).

17. Boonin, supra note 15 , at 70.

18. Id., at 76 .

19. Marquis, supra note 16.

20. D. Marquis, "Justifying the Rights of Pregnancy: The Interest View," Review of Bonnie Steinbock, "Life Before Birth," Criminal Justice Ethics 13, no. 1 (1994): 67-81, at 72.

21. J. McMahan, The Ethics of Killing: Problems at the Margins of Life (New York: Oxford University Press, 2002): at 4.

22 . Or as early as 17 weeks, if Glover and Fisk are right, supra note 14.

23. D. DeGrazia, "Identity, Killing, and the Boundaries of Our Existence," Philosophy छ̛ Public Affairs 31, no. 4 (2003): 413-442, at 427 .

24. Boonin, supra note 15 , at xiv.

25. R. Jaenisch, "Human Cloning - The Science and Ethics of Nuclear Transplantation," New England Journal of Medicine 351, no. 27 (2004): 2787-2791.

26. D. Marquis, supra note 12, at 186.

27. See B. Steinbock, "Respect for Human Embryos," in P. Lauritzen, ed., Cloning and the Future of Human Embryo Research (New York: Oxford University Press, 2001). See also B. Steinbock, "Moral Status, Moral Value, and Human Embryos: Implications for Stem Cell Research," in B. Steinbock, ed., The Oxford Handbook of Bioethics (Oxford: Oxford University Press, forthcoming). 
Copyright of Journal of Law, Medicine \& Ethics is the property of Blackwell Publishing Limited and its content may not be copied or emailed to multiple sites or posted to a listserv without the copyright holder's express written permission. However, users may print, download, or email articles for individual use. 